\title{
SOME THOUGHTS ON RESEARCH
}

\author{
BY THOMAS H. JOHNSON
}

Thomas H. Johnson, Chairman of the English Department at The Lawrenceville School, taught English at Rutgers and at Williams (his alma mater) before going to Lawrencerille in 1937. He has also taught at Columbia, Harvard, and the University of Copenhagen. His active scholarship has produced books on Jonathan Edwards and the Puritans. $\mathrm{He}$ is Co-editor of Literary History of the United States, and prepared the bibliographical volume of that work. His most recent publication is the definitive edition of the text of The Poems of Emily Dickinson.

I REGRET THAT LIBRARIES are necessary. That is one way of saying that I wish I could project myself into all time, for if I could I would be in the position which Woodrow Wilson postulated in the early years of this century, while talking to one of his classes. "I would never read a book," he said during a lecture, "if it were possible for me to talk half an hour with the man who wrote it." I myself would be less modest in my demand on a great man's time. I would want to hear more, for instance, should I happen to be present at the trial of Socrates when, asked to speak in extenuation of his behavior, he declared that for the services which he had rendered to the city, he deserved, not punishment, but the reward of a public benefactor-maintenance in the Prytaneum at the cost of the state. I would extend the time also to listen, to the end, to Cicero's I 7th of March speech in the senate urging a general amnesty for Caesar's murderers, for I cannot fully reconstruct, merely by reading about it, the nuances of his golden periods, persuasive I suppose as few lawyers have ever made them.

It would of course constitute a never-to-be-forgotten experience for any lover of wit and wisdom to drop into one of the London taverns at a moment when Ben Jonson was in top form. For us today only the alembic remains, passed on to us in the lines of Robert Herrick.

\author{
Ah Ben! \\ Say how, or when \\ Shall we thy Guests \\ Meet at those Lyrick Feasts, \\ Made at the Sun,
}


The Dog, the triple Tunne?

Where we such clusters had, As made us nobly wild, not mad;

And yet each Verse of thine

Out-did the meate, out-did the frolick wine.

My Ben!

Or come agen;

Or send to us,

Thy wit's great over-plus;

But teach us yet

Wisely to husband it;

Lest we that Tallent spend:

And having once brought to an end

That precious stock; the store

Of such a wit the world sho'd have no more.

This is all we know. It is much. It is so much, as art, that we undergo a feeling of frustration in not knowing more. What was the stretch of Jonson's mind on such occasions? What was the nature of his wit? Mordant? Fanciful? Outrageous? What comments sparked his raillery or allegiance or anger or sarcasm, or touched him with a silence that restrained the tears? Men like Herrick do not pen such lines unless they have found themselves upon a peak in Darien.

I should like to sit with the men of Cromwell's cavalry by a campfire on the eve of the battle of Naseby, to share in their arguments (for they did so then) on the issue of predestination versus free will. I want to be present when Benjamin Franklin took upon himself the responsibility for the publication of the Hutchinson letters, in the hearing before the privy council at the Cockpit on the 29th of January I774, and was master of his temper and of the scene, while being bated by Wedderburn, the solicitor-general, in language scarcely to be matched for studied insult and invective.

Since at the moment I am engaged in the work of editing the letters of Emily Dickinson, I would especially like to be present on the occasion when Thomas Wentworth Higginson paid a call upon Dickinson, on that quiet August afternoon in 1870 , and was subjected to an experience which, as he described it to his wife, drained him emotionally as no similar encounter ever had done. Somewhere, somehow, somebody other than Higginson must once have noted that historic meeting, and left a record of it, now lost, one conjec- 
tures, because the recorder or his heirs thought the event too trivial to be of interest to others. Perhaps all it said was: "Emily quite exhausted this evening. Col. Higginson seems a most gracious gentleman, though I wish he were less addicted to caraway seeds." Or it may have said: "Tried to keep Emily out of the kitchen tonight, but she insisted on making blackberry jelly. I don't see why she acts so driven."

But alas, such journeys to Glubbdubdrib, where Gulliver experienced whatever ancient and modern history-in-the-making as he chose, cannot be. And in reality, even if the trips could be made, they surely on occasion would be as anticlimactic as an actual experience of mine ten years ago. I was driving home from Princeton one day, with the late afternoon sun in my eyes, by way of a back road, when I saw loom before me two men strolling in the middle of the highway. With their backs to me, they were in absorbed conversation, and one of them by his gesticulations and the mane of white hair, I instantly identified as Einstein. I slowed the car to a stop, none too soon. In some surprise he turned to face me as I leaned from the car and said: "I'm sorry." He smiled and said, "No. I'm sorry." I thus entered and passed out of Einstein's life, on a dramatic plane perhaps, but one hardly significant in the history of ideas.

I began by saying that I regret libraries are necessary. Since I cannot project myself into ALL-TIME, thank God libraries do exist, and that there are depositories like this in which scholars can find not only the recognized tools and the sought-after rarities, but the forgotten railroad or river timetables, the long-since discarded hotel register, the prescription ledger, the handyman's cash book: in sum, that trace of the minute unknown which, when discovered, supplies the critical mass to release the vast energy of a new idea.

I know that in this distinguished assemblage are many persons who have achieved recognized success in working out the problems of depositary libraries. In their presence I feel humble, because they have detailed knowledge of the multifold complexities of assembling great holdings in all the disciplines of learning. I am sure that they would like me to speak for them, for all of us, to our friends who are not here, those who are also lovers of books but are not yet clear about the nature of the problems which scholars face when they are afoot upon the open road. 
Here in this building are catalogued the materials which employ the symbol of the word, as it is expressed in all languages throughout all history. It is the librarian, as such, who takes on the task of curatorship. It is the scholar, as such, who works within the limit of an individual problem. But it is the librarian as scholar who knows how a problem can ramify, and veer in unaccountable directions, and it is such librarians of whom the superhuman is expected, for they set themselves the task of devising ways to meet the never-ending emergencies which a flourishing scholarship is expected to create.

I do not intend to speak of the immense advantages which such a physical plant as this can offer, for we all have eyes to see. But I am sure that Mr. Cameron can feelingly echo today the words of Mark Twain: "Do not undervalue the headache. While it is at its sharpest, it seems a bad investment, but when relief begins, the unexpired remainder is worth four dollars a minute."

What advice can we who are friends of a research library give to those who need our help? Here is one example.

"Yes, I would be happy to further the needs of scholars, but I do not know what they want, and I have no means to purchase rarities. Besides, my own hobbies as a collector would scarcely be of interest to scholars, for I have merely been trying to pick up the few imprints put out by my grandfather, who had a small press for a short time in Cranbury. He enjoyed setting up some of his friends' reminiscences, but the families have all died out and never were important. The books have no value, and I pick them up when I find them only because I was fond of my grandfather."

Or this: "Only the junk dealer would want the stuff in those boxes. I myself don't really know what's in them, except that they contain oddments of books and things I promised Aunt Emeline I would keep as long as she lived. She's the kind that never is willing to throw anything away, but she's ninety now, in a home, and very feeble. I will keep her trust of course while she lives, but I have promised to destroy all personal papers after her death."

Or this: "You and I may as well talk frankly. I know that my uncle was a brilliant, well known, and truly important person. He had his weaknesses, but I want to make everything available that pertains to him, for the public man gives a hostage to fortune. But I do not think such appertains to other members of his family, who 
deserve the veil of protection. This batch of letters written to him by his wife is now going into the incinerator."

Or this: "Sometime when I get around to it, I'm going through that trunk because my cousin told me that he thought his greatuncle may have kept some family letters written to him when he was just out of college." "Who was this cousin's great-uncle?" "The historian and statesman George Bancroft." "Then if letters are there, they are important." "Oh, I doubt it. Bancroft's career is well known. His juvenilia would interest no one." "But surely you are aware that upon graduation from Harvard, Bancroft made a European tour, in the course of which he was intimately received by almost every distinguished man in the world of letters, art, and science; among others, by Goethe, Humboldt, Schleiermacher, Hegel, Byron, Niebuhr, Bunsen, Savigny, Cousin, Constant, and Manzoni?" "Yes, I know. But I'm sure nothing important like that is in the trunk, for everything of importance has long since been examined. Sometime when I'm not busy, as I told you, I'll dig into it."

Dear Friends: The hypothetical dialogues that I have presented are real in the sense that I have engaged in them all. Your vis-à-vis in these situations is educated, sincere, and by intention a friend of learning. But he still needs help. If you cannot cajole such a person yourself, or clarify for him the issue of privacy, or convince him that in the republic of letters nothing is trivial, your greatest service will be to go to the nearest phone, dial Mr. Cameron collect, and say loudly: "Operance, operance, please send the ambulator."

Dryden surely had the research scholar in mind, among others, when he said:

Happy the man, and happy he alone,

He who can call today his own:

He who, secure within, can say,

Tomorrow, do thy worst, for I have lived today.

Libraries like this make such happiness possible for the generations that cherish learning. But they make it possible only if we who are their friends concern ourselves also with the seemingly minute, the trivial, the forgotten, the neglected, the out-of-fashion, the useless, and the impractical. They can do for us what Sir Thomas Browne did not dream could happen in 1658 . 
What Song the Syrens sang, or what name Achilles assumed when he hid himself among women, though puzling questions are not beyond all conjecture. . . . But who were the proprietaries of these bones, or what bodies these ashes made up, were a question above Antiquarianism.

Today the Geiger counter does indeed go above antiquarianism, and the Norfolk burial urns can be made to render up the secrets that Browne had believed inviolable. And why? Because research libraries are concerned with advancing knowledge by supplying material to men and women who do not ask: "What good will it do?" —who never say: "I see no use for it." For now we know that Swift's satire on speculative science in his university of Lagado no longer speaks truth. The swelling chorus now takes up the refrain of Archimedes: "Give me a lever-just a lever-and I will move the world." 